\title{
Public private partnership as city project management technology
}

\author{
Igor Zapivakhin ${ }^{1}$, Igor $\operatorname{Ilin}^{1}$ and Anastasia Levina ${ }^{1, *}$ \\ ${ }^{1}$ Peter the Great St.Petersburg Polytechnic University, Polytechnicheskaya, 29, 195251, \\ St. Petersburg, Russia
}

\begin{abstract}
The paper describes the principle of the public-private partnership as a mechanism for implementing infrastructure projects in cities as well as the forms of organization and financing options for such projects. The basic concepts of the public-private partnership are analyzed. The experience of implementing the public-private partnership in the framework of the project for the construction of the Moscow-Saint Petersburg interstate route is presented. The bottlenecks of the current practice of the public-private partnership were revealed. The purpose of this paper is to propose recommendations for improving the effectiveness of public-private partnership as a form of government-business relations in the Leningrad region based on an analysis of the model of public-private partnership in the region.
\end{abstract}

\section{Introduction}

The current period of Russia's economic development is characterized by active development of strategies for socio-economic development for the long-term period both for the country as a whole and for its individual regions. At the same time, among the main tools for implementing regional development strategies, the use of public-private partnership (hereinafter referred as PPP) as a strategic resource of sustainable economic development and growth of its competitiveness is actualized. PPP is a relatively new instrument of economic development. This form of cooperation arises, first of all, in those spheres for which the state traditionally bears responsibility: public facilities (transport, communal, social infrastructure), renovation, reconstruction and maintenance of public facilities, housing and communal services and much more. The state, as a rule, can not completely abandon its presence in these sectors of the economy, and is compelled to retain control over either certain property or a certain type of activity. But to ensure the preservation and maintenance of the operability of the objects included in them the funding for expenditures at the expense of the corresponding budgets is insufficient. [1] It is required to attract additional capital, which comes through the implementation of forms of cooperation between the state and private business.

The form of interaction between the state and business, known as public-private partnership, originated in the early 1990s. in the UK, when the traditional interaction between the customer (state) and the contractor (business) has replaced the model called the Private Financial Initiative. During this period in England, a law was adopted on a "private 
financial initiative," which facilitated private structures "entry" into the public services sector through a clear definition of framework conditions. In accordance with this model, the state only ordered, but did not pay business for these or any other capital-intensive facilities. After completion of work, the facility was taken by the state for long-term lease, provided that the contractor continued to ensure its operation. That is, investments were returned to the business through rent payments. After the end of the lease period, the object was transferred to the state at a symbolic cost, and sometimes free of charge.

The purpose of this article is to propose recommendations for improving the effectiveness of PPP, as a form of government-business relations, in the Leningrad region on the basis of an analysis of the model of public-private partnership in the region.

\section{Materials and methods}

Initially, PPPs implemented projects, mainly in infrastructure sectors. Gradually, such legal relations began to extend to certain large-scale projects - from the provision of public services to R \& D and the introduction of innovations. It seems reasonable to consider the PPP as an independent economic category. However, the definitions of public-private partnerships have different nuances, depending on the methodological approach adopted by one or another author. In the Russian and foreign literature, PPP is defined in different ways.

Foreign authors define PPPs as "agreements between public and private parties on the production and provision of infrastructure services, concluded with a view to attracting additional investments and, more importantly, as a means of increasing the effectiveness of budget financing" [2]

The definition of this concept is also given by the PPP Center under Vnesheconombank: "it is an involvement of contracting private sector authorities on a contractual basis for more efficient and qualitative execution of tasks related to the public sector of the economy on the basis of cost compensation, risk sharing, obligations, competences."

The legislation of the Leningrad Region contains its definition: public-private partnership is the cooperation of the Leningrad region and a Russian or foreign legal entity or individual established on the basis of the application of the norms of the current legislation of the Russian Federation and this regional law or acting without the formation of a legal entity under a simple partnership agreement joint activity) of association of legal entities in order to implement socially significant projects in Leningrad region on the creation (reconstruction) and (or) operation of the objects of the agreement on the terms of an agreement on public-private partnership».

At the same time, it is necessary to take into account that at present a single definition and, accordingly, an understanding of PPP, even in those countries where it is developing quite successfully, has not yet evolved. The variety of types, forms and spheres of PPP application make it a universal mechanism for solving a number of long-term tasks - from the creation and development of infrastructure to the development and adaptation of new promising technologies. [3,4]

Theoretical and practical bases of interaction between the state and the private sector were developed by many scientists (A. Atkinson, J. Bertram, O. Osborne, M. Porter, D. Stiglitz, G. Fisher, and others). At the same time, the content, forms of public-private partnership, as well as ways of its effective application in the Russian state administration, especially at the local level, have not yet been adequately researched. The urgency and insufficient degree of research determined the purpose and objectives of the study.

The main types of participants in PPP projects are:

- In the manufacturing sector: a contractor company (a concessionaire - this may be a

legal entity specially created to win a tender by a consortium of private partner 
investors); a specially designed project company and / or a management company; contractors (general contractor, subcontractor); suppliers of equipment; buyers of goods and services produced at the site.

- In the financial sector: banks that finance and lend projects; investment banks; international financial organizations, development banks; funds and other financial institutions - institutional investors (acquiring shares and other securities issued by the project company).

- In the insurance sector: insurance companies; guarantor banks.

- In the public sector: state, regional and local budgets; Investment Guarantee Agency.

- Other market institutions and participants (consultants, leasing companies, etc.).

- Civil society institutions (representing the interests of the population).

Specific projects may include more sophisticated mechanisms.

In the Regional Law of the Leningrad Region No. 78-oz "On the participation of the Leningrad Region in public-private partnerships" the following forms of participation:

- property participation of the Leningrad Region in public-private partnerships;

- financial participation of the Leningrad Region in public-private partnerships;

- provision of state support to private partners in accordance with the legislation of the Russian Federation and the legislation of the Leningrad Region;

- other forms that do not contradict the legislation of the Russian Federation and the legislation of the Leningrad Region.

Within the framework of the agreement, one or several forms of participation of the Leningrad region in public-private partnership can be used [5].

The peculiarity of the Russian market environment (starting from the second half of 2007 ) is the creation, on the basis of large-scale production and production complexes, of state corporations with significant powers and capital. [6] These are: the Fund for Assistance in Reforming the Housing and Communal Services, Rosnanotech, the Development Bank, the Olimpstroy Group, Russian Technologies, and the United Aircraft Corporation (OSK) and the State Atomic Energy Corporation Rosatom.

The most common institutional and legal mechanisms of PPP [7]:

- BOT (Build, Operate, Transfer) - the object is created at the expense of the concessionaire and then it is used for the time of recoupment of the invested funds, then the object is returned to the state, and the concessionaire receives the right of use;

- BOOT (Build, Own, Operate, Transfer) - the private partner uses and owns the facility during the term of the agreement, and then it is transferred to the state;

- BTO (Build, Transfer, Operate) - the transfer of the object to the state upon completion of construction with the transfer to private partnership;

- BOO (Build, Own, Operate) - the created object after the expiration of the agreement remains at the disposal of the investor;

- BBO (Buy, Build, Operate): the state sells the facility to the private sector, which improves it for effective management;

- ROT (Rehabilitate, Operate, Transfer);

- RLT (Rehabilitate, Lease, Transfer);

- BROT (Build, Rehabilitate, Operate, Transfer).

- Depending on the amount of responsibility of a private partner, they are distinguished by:

- DB (Design, Build);

- DBO (Design, Build, Operate);

- DBFO (Design, Build, Finance, Operate);

- DBOOT (Design, Build, OWN, Operate, Transfer);

- BOMT (Build, Operate, Maintain, Transfer). 
It is often difficult to determine which of the PPP mechanisms is preferable. So, in the field of water supply and treatment facilities, in various countries different PPP mechanisms are used: public ownership and exploitation - in many countries; public ownership and private management - in France; a model of private financial initiative - in Turkey and China; concessions are common in developing countries; privatization (BOO) in England.

The issue of adequate regulatory and legal regulation of the practice of PPP, especially its financial mechanisms, is of fundamental importance, otherwise it is a significant source of corruption danger or just a cover for the unwillingness of state and municipal authorities to perform certain functions that are traditionally reserved for the public sector of the modern economy. [8]

The realization of its economic mechanism, including the various ways of using those economic resources that are currently at the disposal of public administration, is of great importance for the practice of PPP. These are, first of all, state and municipal finances (budgetary funds), as well as state and municipal property. The movement of these funds is strictly regulated by law, therefore, it is precisely in the implementation of the economic mechanism of PPP that the greatest difficulties arise.

The PPP is based on the concept of project financing (PF). This is the concept of financing investment projects under the guarantee of the expected profit, i.e. those revenues that the enterprise will create during its operation. At PF basic, working capital and cash flows are reflected on the balance sheet of a company specially created for the project. Risks at PF are distributed among all project participants, including the state. [9]

When implementing PPP projects, the state often does not directly invest money, but contributes to the growth of private investment. However, a state participant of PPP is a generator of certain financial flows. So, for example, the participation of the Leningrad region in PPP envisaged by law may include the implementation of the following payments: provision of state guarantees to ensure the proper fulfillment by the partner of obligations arising in connection with borrowing funds for the implementation of the agreement on public-private partnership; placement of orders for the supply of goods, works, services for the state needs of the Leningrad Region; granting subsidies to the partner for the purpose of reimbursement of expenses or incomplete income in connection with the production (sale) of goods, the performance of work, the provision of services when executing the agreement on public-private partnership; provision of budgetary investments to a partner; buy-out of partner property; payment at regulated tariffs (prices) of a certain volume of goods, works, services provided by the agreement and produced by a private partner. [10,11] Within the framework of the agreement on public-private partnership, one or several forms of financial participation of the Leningrad region [5].

The main sources of financing for PPP projects are::

- funds of international financial organizations (MFIs);

- funds of budgets of different levels;

- funds of state enterprises and state institutions;

- bank loans;

- funds of private investors;

- private funds of a private partner in PPPs;

- issue of securities.

The main PPP financing mechanisms:

- Credit (attraction of borrowed funds);

- Mixed (attraction of own funds of partners);

- Hybrid (combination of own and borrowed funds). 
PPP forms are understood as concessions (of various organizational types), leasing, production sharing agreement, state order, etc. The organizational types of PPPs refer to the industry belonging to forms, for example, road concession, forestry, etc. Concessions are the most common form of government-business partnerships. [12] Concession (concession agreement) is a specific form of relations between the state and the private sector. Its peculiarity lies in the fact that the state or municipal entity, within the framework of partnership relations, remaining the full owner of the property constituting the subject of the concession agreement, authorizes the private partner to fulfill the functions stipulated in the agreement within a certain period of time and allocates it for this purpose the relevant powers necessary to ensure normal functioning of the concession object. For the use of state or municipal property, the concessionaire makes a payment on terms stipulated in the concession agreement.

The following characteristic features of the concession [13]:

- The subject of the concession is state (municipal) property, as well as monopolistic activities of the state or municipal entity;

- One of the subjects is a state or a municipality;

- The purpose of the concession is to satisfy public needs and needs;

- The concession always has a contractual basis;

- The concession is based on the returnability of the subject matter of the agreement;

- The subject of the concession is granted to the private partner for a fee determined in the agreement

\section{Results}

In this article, the experience of PPP in Russia is analyzed with the example of one of the first PPP projects in road construction and the largest concession contract in Russia - the construction of the first section of the new toll motorway Moscow-St Petersburg. The length of the future toll highway from Moscow to St. Petersburg will be about $650 \mathrm{~km}$. The width of the roadway is 10 lanes on the outskirts of Moscow, 8 lanes in the Leningrad and Moscow regions and 6 lanes on the territory of the Tver and Novgorod Regions. According to the project, 32 junctions, 85 bridges and 167 overpasses will be built along the road to St. Petersburg, and in St. Petersburg a new route will connect with the road to Finland. The toll route will require investments of about 200-240 billion rubles. The payback period is about 17 years. The total cost of the project is about 60 billion rubles., 23 billion rubles. the Government of the Russian Federation, and the remaining funds are attracted by the concessionaire.

The implementation of the project on the scale of the construction of the "Moscow-Saint Petersburg" highway will help to solve the following social and economic tasks:

- Creation of an effective high-speed automobile communication system between Moscow and St. Petersburg

- Reduce transport costs and improve the quality of related services

- Increase of technical characteristics and capacity of the international transport corridor "North-South" and Pan-European transport corridors No. 2 (East-West) and No. 9

- Increase in the efficient operation and intensity of freight turnover of the Moscow and St. Petersburg transport hubs

- Creation of infrastructure conditions for increasing the investment attractiveness and socio-economic development of the territories of six RF subjects with a population of more than 25 million people. 
- Implementation of new forms of contractual relations, incl. co-investment of extrabudgetary funds during the construction phase and the end-to-end responsibility of the contractor during the construction / operation phase.

The concessionaire is the Russian Federation represented by the State Company "Russian Highways" (GC Avtodor). GC "Avtodor" has all the necessary powers to conclude and implement a concession agreement with the concessionaire in respect of the project, which will be fixed at the disposal of the Government of the Russian Federation. [14]

The obligations of the concessionaire:

- Conclusion of lease / sublease agreements of land plots for which the road will pass and / or which are necessary for the concessionaire to carry out activities related to the construction and operation of the motor road with the concessionaire

- Transfer of the existing design documentation for the construction of a road to the concessionaire

- Granting to the concessionaire a capital grant for the construction of a highway

- Transfer of the road to the concessionaire for possession and use from the date of its commissioning until the expiration of the concession agreement

- Payment to the concessionaire the payment of the concessor from the moment of commissioning of the motor road

- Acceptance of a road from the concessionaire at the end of the concession agreement.

- In accordance with the concession agreement, the concessionaire must ensure:

- Co-financing of construction in the amount of at least $25 \%$ of the total cost of the road

- Commissioning of the road in a period not exceeding 36 months from the date of receipt of the building permit

- Operation as a public road, including but not limited to: maintaining the road in an appropriate transport and operational condition throughout the life of the service; Realization of current and major repairs, the maintenance of a motor road during all term of operation; implementation of other measures to comply with transport performance indicators of the road and its availability indicators for users; the organization of collection of fees from road users in favor of the concessor from the date of putting the road into operation.

- Ensuring the road accessibility indicators required by the concession agreement for users

- Transfer of the road to the concedent upon termination of the concession agreement. In order to implement the project, the concessor provides the following stages of state support:

1. Capital grant during the construction of the motor road

2. The payment of the concessionaire at the stage of operation of the facility.

The total cost of the construction of the facility is 89.15 billion rubles. in the prices of the respective years including VAT. Financing for the construction of the highway will be carried out by the concessor and the concessionaire in the following proportion, respectively: $75 \%$ and $25 \%$.

The amount of state support provided for the construction of a highway will be paid annually to the concessionaire in proportion to the successful completion of the stages according to the following scheme (Figure 1) [14]: 


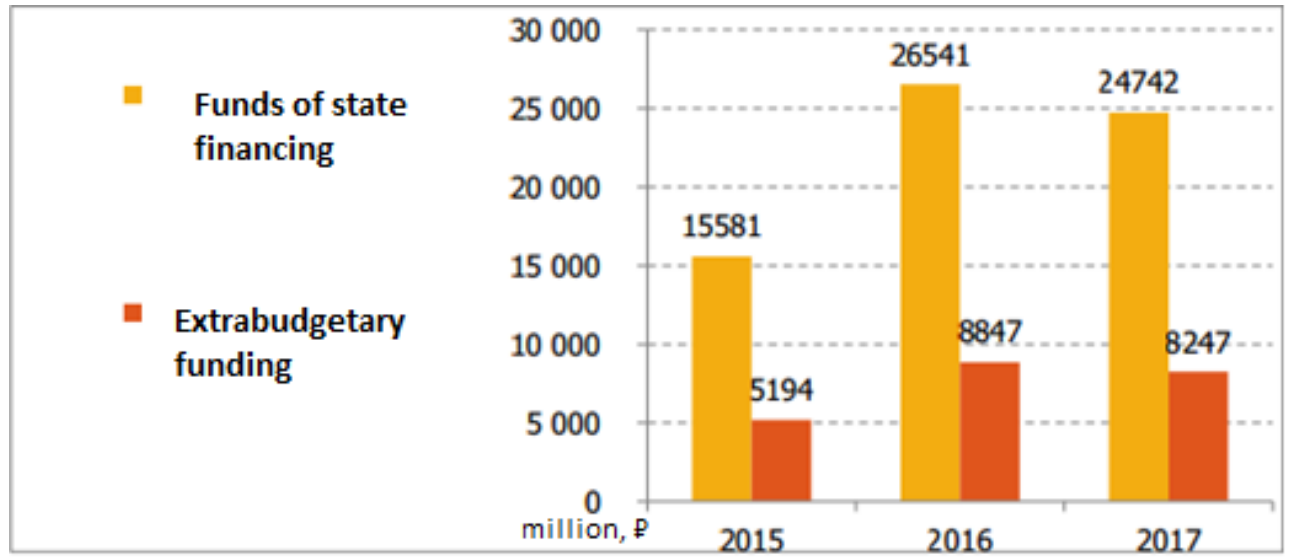

Fig. 1. The amount of state support for the construction of a highway.

\section{Discussion}

The primary problem that cannot be overlooked is the lack of an official understanding and interpretation of the term PPP in Russia. Each expert, the author tries to formulate his definition of PPP. Described in the regional law of the Leningrad region "On the participation of the Leningrad region in public-private partnerships," the definition is narrow-legal in nature, referring to PPP projects certain legal agreements between the state and business, and only in the form of a full partnership. Non-federal definitions, mechanisms and PPPs provide the private sector with many challenges. Now PPP projects are not included in targeted programs. If the Leningrad Region decides to attract private investors for construction, then it will not receive any subsidies from the center. Thus, either the money from the local budget is added to the federal budget allocated for this, or one-on-one with the investor. And if the logic of the state does not change, then the regions will continue to prefer not to look for investors, but to wait peacefully for money from the federal center.

At the moment, the Budget Code of the Russian Federation prohibits the provision of any state guarantees for a period of more than ten years. State obligations to finance any project are limited to a three-year budget beyond which the private partner must bear significant political and economic risks. Here lies another problem - limited access to longterm loans in rubles at fixed rates. Today, the loan period on average is $7-12$ years, and the term of the PPP project is 20-30 years. One solution to this problem may be a long-term contract with a fixed indexation rate.

An equally important problem for Russian companies is the change in the regulatory and legal framework in the area of project implementation. Taking into account that large PPP infrastructure projects are, as a rule, long-term projects, this risk becomes significant. In the rapidly developing and changing regulatory and legal framework in Russia, the changes in the "rules of the game" are quite realistic.

\section{Conclusion}

In conclusion, it can be noted that there are problems in the implementation of PPP projects in the Leningrad Region. To address these problems, it seems appropriate to implement the following measures: 
1. it is necessary to stimulate and raise the level of investment attractiveness of the Leningrad Region;

2. it is necessary to create a single legal framework;

3. it is required to form a system of training specialists on PPP issues;

4. it is necessary to create a bank of successful PPP projects;

5. it is necessary to open access to long-term crediting in rubles at fixed rates;

6. it is necessary to raise the level of awareness of the opportunities and benefits of PPP;

7. it is necessary to provide guarantees for the invested funds (to insure risks).

\section{References}

1. A. Kozlov, E. Rytova, S. Gutman, I. Zaychenko, IEEE Int. Conf. on Soft Comp. and Meas. (SCM), 545 - 547 (2016)

2. J. Delmon, Private Sector Investment in Infrastructure: Project Finance, PPP Projects and Risk (2009)

3. S. Shirokova, E. Naidenysheva, Proc. of the 29th IBIMA, 1150-1156 (2017)

4. T. Alesinskaya, D. Arutyunova, V. Orlova, I. Ilin, S. Shirokova, Acad. of Str. Man. Jour. 16, 10-20 (2017)

5. The regional law of the Leningrad region of 14.10.2011 № 78-oz "On the participation of the Leningrad region in public-private partnerships" (2011)

6. E. Balashova, E. Gromova. RevistaEspacios 38(53), 31 (2017)

7. V. Kabashkin, Public-private partnership in Russian regions (2012)

8. V. Mochalnikov, Federalism, 2 (2007)

9. V. Anisimov, E. Anisimov, M. Sonkin, Int. Jour. of App. Eng. Res. 10(17), 3812738132 (2015)

10. E. Istomin, A. Sokolov, V. Abramov, G. Gogoberidze, N. Popov, SGEM. 1(2), 607614 (2015)

11. G. Gogoberidze, L. Karlin, V. Abramov, J. Lednova, BALTIC 2014, 6887840 (2014)

12. A. Bril, O. Kalinina, A. Levina, E3S Web of Conferences 33, 03004

13. M. Deryabina, Theoretical and practical problems of public-private partnership, www.imepi-eurasia.ru/baner/docladD.doc

14. Official site Avtodor, http://www.russianhighways.ru/ 